\title{
Assessment of anthropometric measurements in diagnosis and monitoring of excessive body weight in children
}

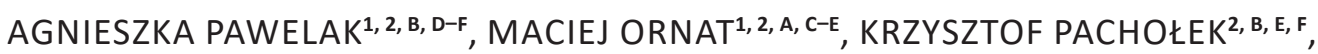 \\ AGNIESZKA WRÓBLEWSKA ${ }^{1,2, \mathrm{~B}, \mathrm{D}-\mathrm{F}}, \mathrm{BARTOSZ}$ JERCZAK $^{3, \mathrm{~B}, \mathrm{D}-\mathrm{F}}$, PAWEŁ BARSKI ${ }^{1, \mathrm{~B}, \mathrm{E}}$, \\ ANGELIKA SAJ'B, E, IWONA PIROGOWICZ ${ }^{3, A}$, B, F
}

\author{
${ }^{1}$ Student Scientific Organization for Health Promotion and Disease Prevention at the Department and Clinic \\ of Geriatrics, Wroclaw Medical University, Poland \\ ${ }^{2}$ Student Scientific Society of Geriatrics and Gerontology at the Department of Geriatrics, Wroclaw Medical \\ University, Poland \\ ${ }^{3}$ Department and Clinic of Geriatrics, Wroclaw Medical University, Poland
}

A - Study Design, B - Data Collection, C - Statistical Analysis, D - Data Interpretation, E - Manuscript Preparation, F - Literature Search, G - Funds Collection

Summary Background. Obesity developing in the early years is one of the most important risk factors for cardiovascular diseases. This contributes to the need for the earliest possible diagnosis of overweight in children. There is a noticeable underdiagnosis of obesity, most often in children between 5 and 12 years of age, as well as in adolescents.

Objectives. The aim of the study was to estimate the correlation between anthropometric measurements that are most commonly used in the diagnosis of obesity.

Material and methods. The study involved 150 children, during their rehabilitation and wellness stay at CRR KRUS in Szklarska Poreba in 2017. The entire group performed basic anthropometric measurements - height, body weight, waist circumference and thickness of the deltoid skin fold. Body composition analysis was performed using the Tanita analyzer.

Results. A statistically significant correlation between the studied parameters was assumed $(p<0.001)$. The parameter showing the highest level of correlation with other measured parameters was the BMI percentile, BMI value and Cole index. Among the parameters not based on growth and weight in the boys' group, the most important was the percentile of the waist circumference $(r=0.76)$, while in the girls' group, the content of adipose tissue $(r=0,74)$.

Conclusions. The BMI and centile BMI results were the parameters of the highest value in the diagnosis and monitoring of excessive body weight in children. In addition, neither weight nor growth measurements should be used to determine the amount and location of adipose tissue.

Key words: obesity, Body Mass Index, body composition, pediatrics, anthropometry, waist circumference.

Pawelak A, Ornat M, Pachołek K, Wróblewska A, Jerczak B, Barski P, Saj A, Pirogowicz I. Assessment of anthropometric measurements in diagnosis and monitoring of excessive body weight in children. Fam Med Prim Care Rev 2018; 20(3): 250-254, doi: https://doi. org/10.5114/fmpcr.2018.78267.

\section{Background}

The awareness of the problem of obesity among children and teenagers is gradually increasing. Thanks to the widespread preventive activities and campaigns promoting a healthy lifestyle to the younger populations, numerous developed countries have succeeded in limiting the increase in the number of children with a confirmed diagnosis of obesity [1]. It has been observed that the percentage of younger populations with overweight is decreasing, which is also the case in Poland. According to data from the year 2010, $17.8 \%$ of Polish students suffered from overweight or obesity, whilst in the year 2014 , only $14 \%$ [2]. Despite this positive trend, it should be noted that the average value of BMI between the years 1975 and 2016 gradually grew by $1 \mathrm{~kg} / \mathrm{m}^{2}$ in Middle Eastern Europe and that this rate was three times higher than among the world population [2]. The consequences of this dramatic rise may appear in the decades to come. It has been proven that obesity developing in early age bears a much higher risk of cardiovascular diseases than obesity developed in adulthood [3]. Moreover, children who are affected by obesity had reduced cognitive performance and presented changes in brain structures responsible for learning and memory compared to their non-obese peers [4]. This may obviously affect their school performance. Considering these facts, there is a necessity for the earliest possible diagnosis of increased body mass among children and teenagers. This may have a positive impact on the quality of their life in its further stages. For the time being, however, figures show that underdiagnosis of obesity predominantly concerns children between the age of 5 and 12 . This is also frequent with teenagers, but comparatively less common among adults [5]. In the diagnostics of abnormal body mass in pediatric patients, doctors tend to adapt BMI with the reference to the applicable centile grids or using the Cole index, which is recommended by the IOTF (International Obesity Task Force). BMI cut-off values may differ between countries; in North America, obesity is diagnosed when $\mathrm{BMI}$ exceeds the $95^{\text {th }}$ centile, but in some European countries, the threshold is marked at the $97^{\text {th }}$ centile. Even though calculating BMI requires two basic parameters (weight and height), which should be obtained during every preventive outpatient visit, underdiagnosis of obesity is frequent. Patel et al. proved that only $18 \%$ of children matching the diagnostic criteria had a documented diagnosis of obesity [6]. WHO defines obesity as "a medical condition in which excess body fat accumulation can impact health negatively". As the definition shows, BMI is 
an intermediary anthropometric index which does not convey any information about the accurate contents of fat tissue in the patient's body. Additionally, more and more attention is drawn to the problem of abdominal obesity, which seems to be more strongly corelated with the risk of cardiovascular factors than general obesity [7]. Epidemiological data shows that abdominal obesity may affect one out of ten children in Poland, and it is more common in boys, especially in older age groups, with eating habits and lack of physical activity being the most relevant risk factors [8]. In the assessment of abdominal obesity, the most frequently used parameters are WC (waist circumference) and WHR (waist height ratio). Another parameter associated with excess fat tissue is skinfold thickness, usually measured above the triceps muscle or in subscapular area. However, its accuracy may be biased by common errors made during measurement [9]. Interestingly, WC was proved to have a stronger correlation with insulin resistance than BMI or skinfold thickness [10]. There has been a growing trend towards the use of body composition analyzers based on bioimpedance, which allows precise estimation of FFM (fat free mass) and FM (fat mass). This low-cost method was validated in tests comparing its accuracy to reference imaging techniques [11]. The ability to adapt so many parameters in diagnosing obesity may facilitate the diagnosis and minimize the frequency of underdiagnosis.

\section{Objectives}

The purpose of this study was to test the correlation between anthropometric indicators predominantly applied in the diagnostics of obesity and body composition estimated by bioimpedance analysis (BIA).

\section{Materials and methods}

\section{Study design and participants}

The analysis of anthropometric parameters and body mass composition were a part of a rehabilitatory stay for children from rural areas held at the Granit Hotel in Szklarska Poreba (Poland). The research was carried out in July 2017. The camp was organized for children with upper respiratory tract disorders. Body mass composition analysis was carried out using the Tanita device.

Anthropometric measurements were the elements of a medical examination which was part of medical care during the rehabilitation treatment camp. Therefore, the authors did not request permission from the bioethical committee.

\section{Data sources/measurement}

We measured parameters such as: body weight, height, thickness of skin folds over the triceps brachii muscle, waist circumference and body composition (content of adipose tissue, muscle tissue, water and bone mass). Additionally, indicators such as BMI, WHtR and Cole index were calculated.

\section{Statistical methods}

Microsoft Excel 2017 was used to prepare the database, while statistical analysis was performed using the Statistica computer program (StatSoft Inc.). To evaluate the distribution curve, the Shapiro-Wilk test was used, while the correlation between the obtained parameters was estimated using the Spearman's rank correlation test. In all analyzed parameters, the value of $p<0.05$ was assumed to be the statistical significance level. There wasn't any missing data, and all planned measurements were performed.

\section{Results}

The analysis of normal distribution revealed that none of the analyzed variables had a normal distribution; therefore, non-parametric tests were used in statistical analysis. We included all obtained data in the further analysis.

\section{Participants and descriptive data}

\begin{tabular}{|c|c|c|c|c|}
\hline \multicolumn{5}{|c|}{$\begin{array}{l}\text { Table 1. Characteristics of the analyzed group of children. The } \\
\text { results are presented as the median, maximum and minimum } \\
\text { values (range) }\end{array}$} \\
\hline \multicolumn{5}{|c|}{ Characteristics of the research group } \\
\hline \multicolumn{2}{|c|}{ Gender } & Girls & Boys & Summary \\
\hline \multicolumn{2}{|c|}{ Population } & 82 & 68 & 150 \\
\hline \multicolumn{2}{|c|}{ Age [years] } & \multicolumn{3}{|l|}{$12(7-15)$} \\
\hline \multirow[t]{3}{*}{ Illness } & $\begin{array}{l}\text { Bronchial } \\
\text { asthma }\end{array}$ & $28.1 \%$ & $42.6 \%$ & $34.7 \%$ \\
\hline & \begin{tabular}{|l|} 
Recurrent up- \\
per respiratory \\
tract infections \\
\end{tabular} & $75.6 \%$ & $60.3 \%$ & $68.7 \%$ \\
\hline & Allergic rhinitis & $14.6 \%$ & $10.3 \%$ & $12.7 \%$ \\
\hline \multicolumn{2}{|c|}{ Weight $[\mathrm{kg}]$} & $\begin{array}{l}46.3 \\
(19.1-98) \\
\end{array}$ & \begin{tabular}{|l|}
46.7 \\
$(21.3-82.4)$ \\
\end{tabular} & \begin{tabular}{|l|}
46.5 \\
$(19.1-98)$ \\
\end{tabular} \\
\hline \multicolumn{2}{|c|}{ Height $[\mathrm{cm}]$} & $\begin{array}{l}154 \\
(117-177)\end{array}$ & \begin{tabular}{|l}
152 \\
$(124-180)$
\end{tabular} & $\begin{array}{l}153 \\
(117-180)\end{array}$ \\
\hline \multicolumn{2}{|c|}{ BMI $\left[\mathrm{kg} / \mathrm{m}^{2}\right]$} & $\begin{array}{l}19.5 \\
(13.1-34.9)\end{array}$ & $\begin{array}{l}19.3 \\
(13-31.6)\end{array}$ & \begin{tabular}{|l}
19.4 \\
$(13-34.9)$
\end{tabular} \\
\hline \multicolumn{2}{|c|}{ FM [\%] } & $\begin{array}{l}26.6 \\
(17.9-46.4)\end{array}$ & \begin{tabular}{|l|}
22.4 \\
$(13-49.1)$
\end{tabular} & \begin{tabular}{|l}
24.8 \\
$(13-49.1)$
\end{tabular} \\
\hline \multicolumn{2}{|c|}{$\begin{array}{l}\text { Waist circumference } \\
{[\mathrm{cm}]}\end{array}$} & $\begin{array}{l}74 \\
(52-103)\end{array}$ & \begin{tabular}{|l|}
75 \\
$(54-110)$ \\
\end{tabular} & \begin{tabular}{|l}
74 \\
$(52-110)$
\end{tabular} \\
\hline \multicolumn{2}{|c|}{ Skin fold [mm] } & $17(7-40)$ & $19(5-40)$ & $18(5-40)$ \\
\hline \multicolumn{2}{|l|}{ WHtR } & $48(40-61)$ & $49(40-76)$ & $49(40-76)$ \\
\hline
\end{tabular}

\section{Main results}

\section{Analysis without grouping}

The mutual correlation between body mass, body weight percentile, $\mathrm{BMI}$, BMI percentile, Cole index, body fat mass, waist circumference percentile, skinfold thickness percentile and WHtR index was, in all cases, statistically significant [Spearman's rank correlation, $p<0.001$ ].

Analysis of the examined parameters depending on gender

Due to the small number of children aged 7 and 8 years, an analysis was not conducted in these age-groups. The analysis was carried out in groups of children 9-15 years of age.

An analysis of correlation values between the examined parameters revealed that the parameter showing the highest level of correlation with other measured parameters was found in the group of girls BMI percentile, the BMI value and Cole index. All these indicators analyze the body weight and height of the examined child. Among the parameters, which are independent of these variables, the content of adipose tissue and WHtR were the most useful. In the group of boys, the highest correlation value with other parameters was also shown by the BMI percentile, BMI and Cole index values. From parameters independent of these variables, the highest value was showed by the waist circumference percentile (Tables 2, 3).

In the group of children aged 9-12 and 14 years, the most useful parameters were: BMI, BMI percentile and Cole index. In the group of children 13 years of age, the body mass percentile along with the above-mentioned parameters were most helpful. In the age group of 15 years, BMI and BMI percentile did not show a sufficient correlation with other parameters, whereas the body mass percentile and Cole index were characterized by a high level of correlation with other parameters. From the group of the remaining elements - not based on body mass and height - the percentile of waist circumference was characterized by the highest level of correlation with other parameters (Table 4). 


\begin{tabular}{|c|c|c|c|c|c|c|c|c|c|c|}
\hline Sex & \multicolumn{10}{|l|}{ Girls } \\
\hline \multirow{10}{*}{ 藏 } & Parameter & $\begin{array}{l}\text { Body } \\
\text { mass }\end{array}$ & $\begin{array}{l}\text { Body } \\
\text { mass } \\
\text { percentile }\end{array}$ & $\mathrm{BM} 1^{1}$ & $\begin{array}{l}\text { BMI } \\
\text { percentile }\end{array}$ & $\begin{array}{l}\text { Content } \\
\text { of adipose } \\
\text { tissue }\end{array}$ & $\begin{array}{l}\text { Waist } \\
\text { circumfer- } \\
\text { ence }^{2}\end{array}$ & Skin fold ${ }^{3}$ & $\mathrm{WHtR}^{4}$ & $\begin{array}{l}\text { Cole } \\
\text { index }\end{array}$ \\
\hline & Body mass & - & 0.76 & 0.92 & 0.73 & 0.72 & 0.57 & 0.50 & 0.56 & 0.73 \\
\hline & $\begin{array}{l}\text { Body mass } \\
\text { percentile }\end{array}$ & 0.71 & - & 0.87 & 0.95 & 0.73 & 0.74 & 0.56 & 0.74 & 0.97 \\
\hline & $\mathrm{BMI}$ & 0.84 & 0.85 & - & 0.91 & 0.80 & 0.71 & 0.60 & 0.75 & 0.89 \\
\hline & BMI percentile & 0.68 & 0.88 & 0.96 & - & 0.78 & 0.76 & 0.62 & 0.84 & 0.97 \\
\hline & $\begin{array}{l}\text { Content of } \\
\text { adipose tissue }\end{array}$ & 0.42 & 0.68 & 0.63 & 0.68 & - & 0.60 & 0.74 & 0.79 & 0.76 \\
\hline & $\begin{array}{l}\text { Waist circumfer- } \\
\text { ence }\end{array}$ & 0.65 & 0.75 & 0.73 & 0.70 & 0.78 & - & 0.49 & 0.82 & 0.78 \\
\hline & Skin fold & 0.71 & 0.68 & 0.72 & 0.64 & 0.76 & 0.86 & - & 0.65 & 0.59 \\
\hline & WHtR & 0.44 & 0.60 & 0.63 & 0.64 & 0.86 & 0.90 & 0.81 & - & 0.77 \\
\hline & Cole index & 0.70 & 0.95 & 0.93 & 0.97 & 0.67 & 0.73 & 0.66 & 0.63 & - \\
\hline
\end{tabular}

${ }^{1} \mathrm{BMI}$ - Body Mass Index; ${ }^{2}$ Waist circumference related to centile charts. Correlation depending on the percentile of waist circumference; ${ }^{3} \mathrm{Skin}$ fold - measured over the triceps brachii muscle, expressed in percentiles; ${ }^{4} \mathrm{WHtR}$ - waist-to-height ratio; ${ }^{5}$ Cole index - [(measured body weight x proper height $-50^{\text {th }}$ percentile)/(measured height $x$ proper body mass $-50^{\text {th }}$ percentile) $\left.\times 100 \%\right]$.

\begin{tabular}{|c|c|c|}
\hline \multirow{2}{*}{$\begin{array}{l}\text { Parameter } \\
\text { Sex }\end{array}$} & \multicolumn{2}{|c|}{ Average correlation coefficient relative to all other elements } \\
\hline & Girls & Boys \\
\hline Body mass & 0.69 & 0.64 \\
\hline Body mass percentile & 0.79 & 0.78 \\
\hline BMI & 0.81 & 0.79 \\
\hline BMI percentile & 0.82 & 0.77 \\
\hline Content of adipose tissue & 0.74 & 0.69 \\
\hline Waist circumference percentile & 0.68 & 0.76 \\
\hline Skin fold percentile & 0.59 & 0.73 \\
\hline WHtR & 0.74 & 0.69 \\
\hline Cole index & 0.81 & 0.78 \\
\hline
\end{tabular}

Table 4. Averaged correlation values (r) between analyzed factors. Only statistically significant correlation values with $p<0.05$ were
taken into account
\begin{tabular}{|l|l|l|l|l|l|l|l|l|}
\hline Parameter & Average correlation relative to all other elements \\
\hline Age & 9 & 10 & 11 & 12 & 13 & 14 & 15 \\
\hline Body mass & 0.8 & 0.86 & 0.9 & 0.86 & 0.73 & $0.81^{3}$ & $0.83^{1}$ \\
\hline Body mass percentile & 0.82 & 0.85 & 0.9 & 0.86 & 0.82 & $0.76^{3}$ & $0.84^{1}$ \\
\hline BMI & 0.87 & 0.89 & 0.93 & 0.86 & 0.78 & $0.81^{3}$ & - \\
\hline BMI percentile & 0.87 & 0.89 & 0.94 & 0.86 & 0.78 & $0.81^{3}$ & - \\
\hline Content of adipose tissue & 0.81 & 0.8 & 0.89 & 0.78 & 0.55 & 0.53 & - \\
\hline Waist circumference percentile & 0.87 & 0.84 & 0.91 & 0.82 & $-*$ & 0.64 & $0.53^{2}$ \\
\hline Skin fold percentile & 0.77 & 0.82 & 0.76 & 0.74 & $-*$ & $0.62^{4}$ & - \\
\hline WHtR & 0.83 & 0.77 & 0.84 & 0.77 & 0.53 & 0.65 & - \\
\hline Cole index & 0.89 & 0.88 & 0.92 & 0.86 & 0.81 & $0.79^{3}$ & 0.86 \\
\hline
\end{tabular}

${ }^{1}$ No correlation with parameters: adipose tissue mass, percentile of skin fold thickness over the triceps brachii muscle, WHtR; ${ }^{2}$ correlation with body mass, body mass percentile and Cole index; ${ }^{3}$ no correlation with the percentile of skin fold thickness over the triceps brachii muscle; ${ }^{4}$ correlation with adipose tissue mass, waist circumference percentile and WHtR.

\section{Discussion}

\section{Key results}

Based on the results obtained, it can be concluded that the $\mathrm{BMI}$ and $\mathrm{BMI}$ centile measurement had the highest correlation with other anthropometric measurements. Among the tested parameters not based directly on the value of body mass and growth, the waist circumference centile turned out to be the most useful. Adipose tissue content showed a positive correlation with overweight and obesity. Differences in the usefulness of this test depending on gender may be connected with 
a higher content of muscle tissue in boys and the distribution of adipose tissue characteristic for the given gender [12]. The measurement of skin fold thickness belongs to the group of inexpensive, easily accessible and non-invasive methods of testing body composition [13]. According to Spanish researchers, skin fold thickness is also an appropriate indication of adipose tissue distribution in children and teenagers and has a positive correlation with general cardiovascular risk [14].

\section{Limitations of the study}

The largest disadvantage of using only the BMI measure is the inability to distinguish adipose tissue mass from lean mass [15]. For this reason, the BMI standards commonly used in adults should not be used to diagnose overweight and obesity in children. Therefore, the use of growth charts appropriate for gender and age is recommended, in which limit points are positioned, depending on the source, on centile 85 and 95 or 90 and 97 , for overweight and obesity, respectively $[16,17]$.

In other analyses, the usefulness of waist circumference centile in pediatric offices was noted, which is supported by the simplicity of performance, evaluation and high effectiveness in prevention of excessive body weight. The test restrictions were underweight and overweight limits, common for a diverse testing group with respect to nationality [18]. The high sensitivity and specificity of this test was shown both in determination of adipose tissue content and predispositions to future occurrence of diseases of civilizations [19]. The changes taking place in the course of growth and puberty have a minor effect on this result [20]. Other authors, apart from the undeniable advantages of bioimpedance, such as simplicity of performance and price of the test, indicate frequent underestimation of measurements performed using this method. Furthermore, the measurement error for adipose tissue is proportional to $\mathrm{BMI}$ and waist circumference [21]. Fluctuations in the quantity of water in the organism depending on age were seen, especially among younger age groups. This may have an effect on the measurement error in the evaluation of adipose tissue content [22].

Unfortunately, measurement of skin fold thickness did not turn out to be the most precise in this study, and the reasons for such results can be due to both inaccuracy and the limited experience of the research persons, as well as in limitations of this method resulting from adipose tissue distribution. According to the authors of studies of anthropometric measurements, an experienced researcher can achieve repeatability of results with differences between individual results up to $5 \%$ [23]. The ratio of subcutaneous adipose tissue to total adipose tissue in the organism is not a constant value and may vary within the population. Additionally, the amount of subcutaneous adipose tissue may remain within the standard in persons with mild undernutrition [13].

\section{Interpretation}

It was proven that BMI has a high correlation with respect to parameters such as WHtR, waist circumference and skin fold, which was also confirmed by this research $[8,24]$. However, for many, the degree of correlation is insufficiently high, which is why the use of BMI in clinical practice, in spite of its simplicity of measurement and calculation, is a disputable issue $[25,26]$.

\section{Generalization}

Many studies confirm that increased BMI for a given age is connected with a higher risk of cardiovascular disease. In addition, in nearly half of children with BMI above centile 97 , at least one disorder occurs which is a part of the metabolic syndrome $[8,27]$. In children, apart from the content of adipose tissue itself, its distribution in the organism is essential. In the case of the identical total content of adipose tissue in the tested children, its location will have an effect on the risk of cardiovascular diseases [28, 29].

\section{Conclusions}

In summary, it can be concluded that none of the discussed tests fulfils all the criteria for an ideal diagnostic test for obesity in children and predilection for the occurrence of metabolic syndrome and cardiovascular incidents in adulthood.

The parameters showing the highest value in the monitoring of children's body mass (which correlates in the highest degree with all other measured parameters) in almost all studied groups are: BMI value, BMI percentile and Cole index - all based on height and body mass.

Among the factors which are not based on body height and weight, the most useful indicator in the group of boys seems to be percentile of waist circumference, while among girls - the content of adipose tissue.

Source of funding: This paper was developed using funds from the university.

Conflict of interest: The authors declare no conflict of interests.

\section{References}

1. Abarca-Gómez L, Abdeen ZA, Hamid ZA, et al. Worldwide trends in body-mass index, underweight, overweight, and obesity from 1975 to 2016: a pooled analysis of 2416 population-based measurement studies in 128.9 million children, adolescents, and adults. Lancet 2017; 390(10113): 2627-2642.

2. Mazur J. Zdrowie i zachowania zdrowotne młodzieży szkolnej w Polsce na tle wybranych uwarunkowań socjodemograficznych. Raport z badań HBSC 2014. Warszawa: Instytut Matki i Dziecka; 2015 (in Polish).

3. Litwin SE. Childhood obesity and adulthood cardiovascular disease: quantifying the lifetime cumulative burden of cardiovascular risk factors. JACC 2014; 64(15): 1588-1590.

4. Bauer CCC, Moreno B, González-Santos L, et al. Child overweight and obesity are associated with reduced executive cognitive performance and brain alterations: a magnetic resonance imaging study in Mexican children. Pediatr Obes 2015; 10(3): 196-204.

5. Miller EO, Stanistreet B, Ruckdeschel E, et al. Factors Associated with the accurate diagnosis of obesity. J Community Health 2016; 41(6): 1257-1263.

6. Patel Al, Madsen KA, Maselli JH, et al. Underdiagnosis of pediatric obesity during outpatient preventive care visits. Acad Pediatr 2010; 10(6): 405-409.

7. Kelishadi R, Mirmoghtadaee $\mathrm{P}, \mathrm{Najafi} \mathrm{H}$, et al. Systematic review on the association of abdominal obesity in children and adolescents with cardio-metabolic risk factors. J Res Med Sci 2015; 20(3): 294-307.

8. Suder A, Janusz $M$, Jagielski P, et al. Prevalence and risk factors of abdominal obesity in Polish rural children. HOMO 2015; 66(4): 357-368.

9. Freedman DS, Katzmarzyk PT, Dietz WH, et al. Relation of body mass index and skinfold thicknesses to cardiovascular disease risk factors in children: the Bogalusa Heart Study. Am J Clin Nutr 2009; 90(1): 210-216. 
10. Moreno LA, Pineda I, Rodriguez G, et al. Waist circumference for the screening of the metabolic syndrome in children. Acta Paediatr 2002; 91(12): 1307-1312.

11. Pietrobelli A, Andreoli A, Cervelli V, et al. Predicting fat-free mass in children using bioimpedance analysis. Acta Diabetol 2003; 40(1): 212-215.

12. Faria ER, Faria ER, Cecon RS, et al. Body fat equations and electrical bioimpedance values in prediction of cardiovascular risk factors in eutrophic and overweight adolescents. Int J Endocrinol 2013; 1-10, doi: http://dx.doi.org/10.1155/2013/501638.

13. Jiménez EG. Body composition: assessment and clinical value. Endocrinol Nutr 2013; 60(2): 69-75.

14. Sarría A, García LA, Moreno LA, et al. Skinfold thickness measurements are better predictors of body fat percentage then body mass index in male Spanish children and adolescents. Eur J Clin Nutr 1998; 52(1): 573-576.

15. Freedman DS, Sherry B. The validity of BMI as an indicator of body fatness and risk among children. Pediatrics 2009; 124(1): 23-34.

16. Witkowska M, Lesiów T. Występowanie nadwagi i otyłości wśród dzieci w wieku od 10 do 13 lat w mieście i gminie Ostrzeszów. Nauki Inżynierskie i Technologie 2014; 3(14): 51-73 (in Polish).

17. Weber DR, Leonard MB, Shults J, et al. A comparison of Fat and Lean Body Mass Index to BMI for the identification of metabolic syndrome in children and adolescents. J Clin Endocrinol Metab 2014; 99(9): 3208-3216.

18. Schröder H, Ribas L, Koebnick C, et al. Prevalence of abdominal obesity in Spanish children and adolescents. Do we need waist circumference measurements in pediatric practice? PLoS One 2014; 9(1): e87549.

19. Mazıcıoğlu MM, Hatipoğlu N, Öztürk A, et al. Waist circumference and mid-upper arm circumference in evaluation of obesity in children aged between 6 and 17 years. J Clin Res Pediatr Endocrinol 2010; 2(4): 144-150.

20. Nagy P, Kovacs E, Moreno LA, et al. Percentile reference values for anthropometric body composition indices in European children from the IDEFICS study. Int J Obes (Lond) 2014; 38(1): 15-25.

21. Jakubowska-Pietkiewicz E, Prochowska A, Fendler W, et al. Porównanie metod pomiaru odsetka tkanki tłuszczowej u dzieci. Pediatr Endocrinol Diabetes Metab 2009; 15(1): 246-250 (in Polish).

22. Rush EC, Bristow S, Plank LD, et al. Bioimpedance prediction of fat-free mass from dual-energy X-ray absorptiometry in a multi-ethnic group of 2-year-old children. Eur J Clin Nutr 2013; 67(2): 214-217.

23. Lukaski HC. Methods for the assessment of human body composition: traditional and new. Am J Clin Nutr 1987; 46(4): 537-556.

24. Lizak D, Budzowski A, Seń M, et al. Anthropometric measures of body composition used in obesity diagnosis - an overview. Hygeia Public Health 2016; 51(2): 124-133.

25. Johnson TW, Spurlock AY, Parrot JS, et al. A comparison of field methods to assess body fat of minority elementary school children. Int J Body Compos Res 2011; 9(4): 141-146.

26. Rodea-Montero ER, Evia-Viscarra ML, Apolinar-Jiménez E. Waist-to-Height Ratio is a better anthropometric index than waist circumference and BMI in predicting metabolic syndrome among obese Mexican adolescents. Int J Endocrinol 2014; 195407, doi: $10.1155 / 2014 / 195407$.

27. Reilly JJ, Kelly J. Long-term impact of overweight and obesity in childhood and adolescence on morbidity and premature mortality in adulthood: systematic review. Int J Obes (Lond) 2011; 35(7): 891-898.

28. Zhang YX, Wang SR. Distribution of subcutaneous fat and the relationship with blood pressure in obese children and adolescents in Shandong, China. Paediatr Perinat Epidemiol 2015; 29(2): 156-161.

29. Car Staiano AE, Gupta AK, Katzmarzyk, PT. Cardiometabolic risk factors and fat distribution in children and adolescents. J Pediatr 2014; 164(3): 560-565.

Tables: 4

Figures: 0

References: 29

Received: 14.04.2018

Reviewed: 16.04.2018

Accepted: 24.06.2018

Address for correspondence: Iwona Pirogowicz, MD, PhD

Katedra i Klinika Geriatrii UM

ul. M. Skłodowskiej-Curie 66

50-369 Wrocław

Polska

Tel.: +48 71 784-25-21

E-mail: iwona.pirogowicz@umed.wroc.pl 